HIV DIALOGUES AND MANAGEMENT

\title{
Simple guidelines for HIV testing in the physician's practice
}

This monthly series was developed from the AOA Task Force on AIDS Writers' Workshop, held August 16 to 18, 1991, in New York. The workshop was sponsored by an education grant from Burroughs Wellcome. It will provide brief clinical updates and perspectives on the human immunodeficiency virus (HIV). Readers may request tear sheets from the AOA editorial offices.

(Key words: AIDS, HIV infection, HIV transmission, infection control, communicable diseases, sexually transmitted diseases, HIV antibody testing, ELISA)

\section{Question}

What are the simple guidelines for HIV testing that I can follow in my practice?

\section{Answer}

Certainly, there has not been a laboratory test that has brought more controversy to the medical profession, our patients, and the public in general than detection of the human immunodeficiency virus (HIV) antibody. The reasons for this controversy are complex but relate to the fact that AIDS not only has represented a serious sexually transmitted disease and a public health problem, but a contested political issue as well. Fortunately, the recent past has seen the beginnings of both AIDS and HIV testing being treated as a more routine part of medical practice.

The issues most important to the practicing physician regarding HIV antibody testing include who to test, how to test, and legal ramifications.

Choosing appropriate patients for HIV an- tibody testing is based on the behavioral history, the medical history, the findings on physical examination, and other laboratory tests. These aspects have been discussed in detail in the second and third articles of this series (JAOA 1992;92:234-235, 370-372). Once you decide to perform HIV antibody testing, you will have to deal with several issues.

First, each state has its own policies and laws regarding HIV antibody testing, and you should familiarize yourself with them. Most deal with confidentiality, informed consent, and requirements for documentation. Most medical groups, medical legal experts, and bioethicists do agree that the majority of HIV testing both for screening and for diagnosis should be voluntary. Thus, informed consent, consistent with your hospital and state policies and laws, should be obtained. In most areas, simple oral consent is adequate. At times, anonymous testing through a public health clinic may be best for a totally healthy patient who has yet to obtain health insurance or is considering changing jobs. You should discuss such options. For diagnostic purposes, confidential office testing or hospital-based testing is preferable.

A second point to consider is the tremendous importance of the confidentiality of the test results. This information should not be openly relealed to any other individual without a medical or a legal right to know it.

Third, never give a patient a positive result based on a screening test alone. HIV testing is always done as a two-part tandem test with a screening component (enzyme-linked immunosorbent assay, or ELISA) and a confirmatory component generally done by the Western blot technique. Always wait for the results of the 
confirmatory test before concluding results are positive.

Fourth, both positive and negative test results should be given to the patient in person and explained. When test results are negative in individuals with high-risk behavior, these patients need to be told how to continue to be uninfected. Individuals with positive test results need to understand what the test means; namely, that it is not a test for AIDS, but it does tell us that they are infected and are potentially infectious to others on a sexual or blood-borne basis. They also may need individual counseling and assistance in dealing with the emotional trauma of this devastating news.

Finally, infected patients need prompt evaluation or referral to determine their current stage of HIV infection and their possible need for antiviral or antimicrobial therapy (to be discussed in articles 7 and 8 of this series, respectively).
LEONARD H. CALABRESE, DO

Head, Section on Clinical Immunology

The Cleveland Clinic

Cleveland Heights, Ohio and

DAVID CONDOLUCI, DO

Chairman, Division of Infectious Disease Associate Professor of Clinical Medicine University of Medicine and Dentistry of New Jersey-School of Osteopathic Medicine

Stratford, NJ

\section{HIV resource file}

\section{AIDS/HIV hotlines}

Centers for Disease Control National AIDS Hotline 1-800-342-AIDS (English)

1-800-344-SIDA (Spanish)

1-800-AIDS-TTY (Deaf Access)

(919) $361-8425$ (Fax)

$\square$ National AIDS Clearinghouse PO Box 6003

Rockville, MD 20849-6003

1-800-458-5231 (Reference Specialists)

(301) 217-0023 (International)

1-800-243-7012 (Deaf Access)

(301) 738-6616 (Fax)

-Clinical Trials and Drug Information 1-800-TRIALS-A

$\square$ National Sexually Transmitted Diseases Hotline/American Social Health

Association 1-800-227-8922

$\square$ National Gay Task Force AIDS

Information Hotline

1-800-221-7044

(212) 807-6016 (New York State)

\section{Information Sources}

$\square$ US Public Health Service Public Affairs Office

Hubert H. Humphrey Building

Room 725-H

200 Independence Ave, SW

Washington, DC 20201

(202) 245-6867
Local Red Cross or American Red Cross AIDS Education Office

$1730 \mathrm{D} \mathrm{St}, \mathrm{NW}$

Washington, DC 20006

(202) $737-8300$

American Association of Physicians for Human Rights

PO Box 14366

San Francisco, CA 94114

(415) 558-9353

$\square$ AIDS Action Council

729 Eighth St, SE

Suite 200

Washington, DC 20003

(202) 547-3101

$\square$ Gay Men's Health Crisis

PO Box 274

132 West 24th St

New York, NY 10011

(212) 807-6655

$\square$ Hispanic AIDS Forum

c/o APRED

853 Broadway

Suite 2007

New York, NY 10003

(212) $870-1902$ or $870-1864$

$\square$ Los Angeles AIDS Project 7362 Santa Monica Blvd Los Angeles, CA 90046 (213) 876-AIDS

Minority Task Force on Aids co New York City Council of Churches 475 Riverside Dr, Rm 456

New York, NY 10115

(212) $749-1214$ 